\title{
The Concentration Dependence of Active Potassium Transport in the Human Red Blood Cell *
}

\author{
John R. Sachs † and Louis G. Welt $\ddagger$ \\ (From the Department of Medicine, University of North Carolina School of Medicine, \\ Chapel Hill, N.C.)
}

\begin{abstract}
Summary. The relation between the active potassium influx in the human red blood cell and the extracellular potassium concentration does not appear to be consistent with the Michaelis-Menten model, but is adequately described by a model in which two potassium ions are required simultaneously at some site or sites in the transport mechanism before transport occurs. The same type of relation appears to exist between that portion of the sodium outflux that requires the presence of extracellular potassium and the extracellular potassium concentration. Rubidium, cesium, and lithium, which are apparently transported by the same system that transports potassium, stimulate the potassium influx when both potassium and the second ion are present at low concentrations, as is predicted by the two-site model.
\end{abstract}

\section{Introduction}

The human red blood cell concentrates potassium and extrudes sodium against electrochemical gradients. The magnitude of both the active potassium influx and of a portion of the sodium outflux is a function of extracellular potassium concentration. The form of this relation has been of considerable interest. Shaw (1), using the horse red blood cell, and Glynn (2), using the human red blood cell, have reported that the relation between the active potassium influx and the extracellular potassium concentration can be adequately described by a model of the Michaelis-Menten type. Glynn (2) has also shown that in the human red blood cell the re-

\footnotetext{
* Submitted for publication June 6, 1966; accepted September 22, 1966.

This research was supported by U. S. Public Health Service research grants 5-RO1-HE-01301 and AM-08458 and training grant T1-AM-5054.

† Work done during the term of U. S. Public Health Service postdoctoral fellowship 5F2-AM-19, 537.

Present address: Dept. of Hematology, Division of Medicine, Walter Reed Army Institute of Research, Washington, D. C.

$\ddagger$ Work done during tenure of U.S. Public Health Service Research Career Award 5-K6-AM-934.

Address requests for reprints to Dr. Louis G. Welt, Dept. of Medicine, University of North Carolina School of Medicine, Chapel Hill, N. C.
}

lation between the magnitude of that portion of the sodium outflux that is dependent on the presence of extracellular potassium and the potassium concentration is adequately described by a Michaelis-Menten model. Hoffman (3), however, has found that, in the rat red blood cell, a plot of sodium outflux against extracellular potassium concentration yields a sigmoid curve, which is inconsistent with the Michaelis-Menten model. He has interpreted this as indicating that more than one potassium ion is required for activation of the transport system. We have reinvestigated the relation in the human red blood cell and have found that, at low extracellular potassium concentrations, the situation is similar to that in the rat red blood cell. We have interpreted this in terms of a model in which the simultaneous presence of two potassium ions is required at some site or sites in the transport system in order for that system to perform.

It has been shown that rubidium and cesium are concentrated within the human red blood cell, and the transport of these ions appears to be competitive with the transport of potassium so that it has been proposed that all are transported by the same system (4-6). McConaghey and Maizels (7) have reported similar findings in human red blood cells whose internal ionic com- 
position was altered by exposure of the cells to lactose solution in order to render the cell permeable to cations, and subsequently to calcium to restore membrane impermeability. In addition, they have presented evidence that in this preparation lithium is actively transported inwardly, and the lithium influx is competitive with potassium influx. We have found that the behavior of the active potassium influx in the presence of rubidium, cesium, and lithium is consistent with a model requiring the simultaneous presence of two potassium ions.

\section{Methods}

Glossary. In this paper, the following symbols will be used. $M$ represents unidirectional flux. The superscript to the left of $M$ will be either $i$ or o to indicate influx or outflux, respectively. Superscripts to the right of $M$ will be $T$ for total, P for the active component of transport ("pump"), or $\mathrm{L}$ for the passive component of transport ("leak"). Subscripts will indicate the ion whose flux is under discussion. The lower case letter, $k$, will indicate the rate constant. ${ }^{i} \mathbf{M}_{\mathbf{K}}{ }^{\mathbf{T}}$ is total potassium influx (millimoles per liter red blood cells per hour). ${ }^{i} \mathrm{M}_{\mathrm{K}}{ }^{\mathrm{L}}$ is that portion of the potassium influx attributable to nonenergy-requiring diffusional processes (millimoles per liter red cells per hour). ${ }^{i} \mathbf{M}_{\mathbf{K}}{ }^{\mathrm{P}}$ is that portion of the potassium influx due to energy-requiring processes, i.e., ${ }^{i} \mathbf{M}_{K^{T}}-{ }^{i} M_{K}{ }^{L}$ (millimoles per liter red cells per hour). ${ }^{i} k_{K}$ is ${ }^{i} M_{K} /\left[K_{o}\right]$, where $\left[K_{o}\right]$ is the concentration of potassium in the medium (millimoles per liter red cells per hour per millimole per liter $\mathrm{K}_{\mathrm{o}}$ ). ${ }^{\circ} \mathrm{o}_{\mathrm{Na}}$ is the "rate constant" for sodium outflux, i.e., the fraction of the total intracellular sodium extruded each hour (hour ${ }^{-1}$ ). ${ }^{\circ} k_{K}$ is the "rate constant" for potassium outflux, i.e., the fraction of the total intracellular potassium extruded each hour (millimoles per liter red cells per hour per millimole per liter $\mathbf{K}_{\mathbf{i}}$ ).

Solutions. All salt solutions were made up to an osmolality of $295 \pm 5 \mathrm{mOsm}$ per $\mathrm{kg}$ water except for the $\mathrm{MgCl}_{2}$ wash solution, which was used at an osmolality of $280 \pm 5$ mOsm per $\mathrm{kg}$ water. Glycylglycine- $\mathrm{MgCO}_{3}$ buffer was adjusted to $\mathrm{pH} 7.4 \pm 0.05$ at $37^{\circ} \mathrm{C}$ and made to an osmolality of $295 \pm 5 \mathrm{mOsm}$ per $\mathrm{kg}$ water. All inorganic salts used were reagent grade except for rubidium chloride and cesium chloride, which were Specpure. ${ }^{1}$ Whenever a salt solution was varied in concentration, it was replaced by a solution containing $80 \% \mathrm{MgCl}_{2}$ and $20 \%$ glycylglycine$\mathrm{MgCO}_{3}$ buffer solutions so that the final chloride concentration was approximately equal to that of an isosmotic solution of the chloride salt of an alkali metal, i.e., 160 mmoles per L. In all solutions, unless otherwise stated, glycylglycine- $\mathrm{MgCO}_{3}$ buffer was present at a concentration of $10 \%$, and glucose, when present, was at a concentration of 9 mmoles per L. Phosphate was added as an isosmotic

1 Johnson, Matthey, London, England; American affiliate, Jarrell-Ash, Boston, Mass. sodium or potassium phosphate buffer adjusted to $\mathrm{pH} 7.4$ \pm .05 ; the final phosphate concentration was in all cases 1.2 mmoles per L. Strophanthidin was added as an ethanol solution, and equal quantities of ethanol were added to corresponding flasks that did not receive strophanthidin; ethanol when used was in all cases present at $1 \% \mathrm{vol} / \mathrm{vol}$ final concentration.

Potassium influx studies. To obtain an estimate of both the active and nonactive components of the potassium influx, we had to obtain cells depleted of ATP and cells in which ATP levels had been restored. Venous blood from human volunteers was obtained with heparin (500 U per $\mathrm{ml}$ ) as the anticoagulant. The cells were separated by centrifugation and plasma and buffy coat removed by aspiration; the cells were then washed (by resuspension, centrifugation, and aspiration of the supernatant) six times in an isosmotic $\mathrm{NaCl}$ solution (to reduce intracellular glucose). The cells were placed, at approximately $20 \%$ hematocrit, in a solution consisting of $10 \%$ glycylglycine- $\mathrm{MgCO}_{3}$ buffer solution, $1 \%$ sodium phosphate buffer solution, $69 \%$ $\mathrm{KCl}$ solution, $20 \% \mathrm{NaCl}$ solution, 2 million $\mathrm{U}$ per $\mathrm{L} \mathrm{Na}$ penicillin $\mathrm{G}$, and $2 \mathrm{~g}$ per $\mathrm{L}$ streptomycin sulfate. The cells were incubated in this solution at $37^{\circ} \mathrm{C}$ for 15 to 20 hours (to deplete intracellular ATP stores); the solution was changed once after 6 hours of incubation. The depleted cells were then separated from the incubating solution, washed three times in isosmotic $\mathrm{NaCl}$ solution, and divided into two parts. Half were placed in a solution composed of $10 \%$ glycylglycine- $\mathrm{MgCO}_{3}$ buffer solution, $1 \%$ sodium phosphate buffer, and $89 \%$ isosmotic $\mathrm{NaCl}$ solution. The other half were placed in a similar solution containing, in addition, glucose, $500 \mathrm{mg}$ per $100 \mathrm{ml}$; adenine, 3 mmoles per L; and inosine, 10 mmoles per L. Thus, half of the cells remained depleted of ATP and were used in the determination of passive potassium influx; in the other half ATP levels were repleted, and these were used in the determination of the total potassium influx. At the end of 2 hours of incubation at $37^{\circ} \mathrm{C}$ in these solutions, the cells were separated, washed three times in an isosmotic $\mathrm{NaCl}$ solution, and finally added to the appropriate solutions for determining potassium influx. The intracellular sodium concentration after these manipulations remained approximately normal, i.e., 8 to 15 mmoles per $\mathrm{L}$ red blood cells.

Cells prepared as described above were placed at less than $5 \%$ hematocrit in the appropriate prewarmed $\left(37^{\circ} \mathrm{C}\right)$ experimental solutions containing ${ }^{2} \mathrm{~K}$. The system was allowed to equilibrate for approximately 30 minutes, and a sample was poured into ice-cold tubes. The cells were rapidly separated from the supernatant at $0^{\circ} \mathrm{C}$ and washed three times in ice-cold $\mathrm{MgCl}_{2}$ wash solution; the entire process consumed approximately 30 minutes. The cells were hemolyzed, brought to standard volume with distilled water, and counted in a well-type scintillation counter; a sample of supernatant was similarly counted. A second specimen was taken exactly 1 hour after the first and treated in exactly the same manner. The quantity of cells counted was determined by bringing the sample counted to $25 \mathrm{ml}$ and determining the hemoglobin concentration by the cyanmethemoglobin method. The volume of cells counted was estimated assuming that $100 \mathrm{ml}$ of cells con- 
tained $34 \mathrm{~g}$ hemoglobin. Potassium influx was calculated with the relation,

$$
{ }^{\mathrm{i}} \mathrm{M}_{\mathrm{K}}=\frac{{ }^{2} \mathrm{~K}_{\mathrm{c}}{ }^{*}-{ }^{1} \mathrm{~K}_{\mathrm{c}}{ }^{*}}{\overline{\mathrm{K}_{\mathrm{o}}{ }^{*}}}\left[\overline{\mathrm{K}_{\mathrm{o}}}\right] \text {, }
$$

where ${ }^{i} M_{K}$ is the influx of potassium in millimoles per liter red cells per hour, ${ }^{1} \mathrm{~K}_{\mathbf{c}}{ }^{*}$ is the activity of the cells in counts per minute per milliliter cells at 30 minutes, and ${ }^{2} \mathrm{~K}_{\mathrm{c}}{ }^{*}$ is the same quantity at 90 minutes; $\overline{\mathrm{K}}_{\mathrm{o}}{ }^{*}$ is the average of the activity in counts per minute per milliliter of the supernatant at 30 and 90 minutes, and $\left[\overline{K_{0}}\right]$ is the average of the potassium concentration of the supernatant in millimoles per liter at 30 and 90 minutes.

This calculation neglects the effect of back diffusion of isotope from cells to medium. The error attributable to this effect was in all cases calculated to be less than $2 \%$.

The derivation of the equation for the calculation of potassium influx assumes that $\mathrm{K}_{\mathbf{s}}{ }^{*}$ (the activity of each supernatant) and $\left[\mathrm{K}_{\mathrm{o}}\right]$ remain constant during the course of the measurement. Since the hematocrit was low $(<5 \%)$, this was approximately true except at very low levels of $\left[\mathrm{K}_{0}\right]$, when $\left[\mathrm{K}_{0}\right]$ increased over a 1-hour period by $0.08 \mathrm{mmole}$ per $\mathrm{L}$. Averages of the values of $\mathrm{K}_{\mathrm{s}}{ }^{*}$ and $\left[K_{0}\right]$ at 30 and 90 minutes were used to minimize errors due to variations in these terms.

Sodium outflux studies. Cells were obtained as above, plasma and buffy coat were removed, and the cells were washed three times in isosmotic $\mathrm{NaCl}$ solution. The cells were then loaded with ${ }^{24} \mathrm{Na}$ by incubating them for 3 hours at $37^{\circ} \mathrm{C}$ in a solution containing $10 \%$ isosmotic sodium phosphate buffer solution and $90 \%$ isosmotic $\mathrm{NaCl}$ solution containing ${ }^{24} \mathrm{Na}$; glucose was present at a concentration of $500 \mathrm{mg}$ per $100 \mathrm{ml}$. After 3 hours, cells were separated from the isotope solution by centrifugation and washed three times with isosmotic $\mathrm{NaCl}$ solution. A portion of these cells was then suspended in isosmotic $\mathrm{NaCl}$ solution, and hematocrit and hemoglobin concentration were determined; a second portion was rapidly (approximately 15 minutes) washed three times at $0^{\circ} \mathrm{C}$ in isosmotic $\mathrm{MgCl}_{2}$ solution and hemolyzed in distilled water, and sodium and potassium concentration and hemoglobin concentration were determined in the supernatant.

A third portion of the cells was added at a final/hematocrit of $0.2 \%$ or less to the appropriate prewarmed $\left(37^{\circ} \mathrm{C}\right)$ test solution and the suspension incubated at that temperature. After thorough mixing, a sample of the suspension was removed, and the cells were hemolyzed by addition of a nonionic detergent (Acationox); this sample will be referred to as "medium." After 10 minutes of equilibration, a second sample was taken, cells were separated from the supernatant, and the supernatant was collected. Samples were taken in this manner every 15 minutes over a 75-minute period. Samples of the medium and each supernatant were taken for counting, and the hemoglobin concentration was estimated by measuring optical density at $415 \mathrm{~m} \mu$. The fractional hemolysis was calculated by dividing the optical density of each supernatant by that of the medium.

The outflux rate constant, ${ }^{\circ} k_{\mathrm{Na}}$ (i.e., the portion of the intracellular sodium extruded in each hour), was calculated by a method devised by Hoffman (8). The basic predica- tion underlying the method is that the sodium outflux is a first-order occurrence, i.e.,

$$
\frac{\mathrm{dNa}_{\mathrm{c}}{ }^{*}}{\mathrm{dt}}=-{ }^{\circ} \mathrm{k}_{\mathrm{Na}} \mathrm{Na}_{\mathrm{c}}{ }^{*}
$$

where $\mathrm{Na}_{\mathrm{c}}{ }^{*}$ is the activity of the cells in counts per minute per milliliter cells. Over the short time periods involved, the observed data are consistent with this formulation. From this Hoffman has devised the relation,

$$
{ }^{\circ} k_{\mathrm{Na}} \mathrm{t}=-\ln \frac{1-\mathrm{Na}_{\mathrm{s}}{ }^{*} / \mathrm{Na}_{\mathrm{m}}{ }^{*}}{1-\text { fractional hemolysis }},
$$

where $\mathrm{Na}_{8}{ }^{*}$ is the activity of each supernatant in counts per minute per milliliter, and $\mathrm{Na}_{\mathrm{m}}{ }^{*}$ is the activity of the medium; the relation is derived with the stipulation that the hematocrit be low (<ca. $0.3 \%$ ). Values of

$$
\ln \frac{1-\left(\mathrm{Na}_{\mathrm{s}}^{*} / \mathrm{Na}_{\mathrm{m}}{ }^{*}\right)}{1-\text { fractional hemolysis }}
$$

are plotted against $t$, and ${ }^{\circ} k_{\mathrm{Na}}$ (the rate constant) is the slope of the line calculated by the method of least squares.

Potassium outflux studies. Determinations of potassium outflux were made in a manner similar to that described for sodium outflux studies except that the cells were loaded with ${ }^{42} \mathrm{~K}$ by incubating at $37^{\circ} \mathrm{C}$ for 12 to 18 hours in a solution containing sodium phosphate buffer solution, $9 \%$; isosmotic $\mathrm{NaCl}$ solution, $81 \%$; and the remainder $\mathrm{KCl}$ solution containing ${ }^{42} \mathrm{~K}$. Glucose was present at a concentration of $500 \mathrm{mg}$ per $100 \mathrm{ml}$; penicillin G, 2 million $U$ per $\mathrm{L}$, and streptomycin sulfate, $2 \mathrm{~g}$ per $\mathrm{L}$, were also present. The cells were added at a hematocrit of $25 \%$. After the cells had been washed in isosmotic $\mathrm{NaCl}$ solution, they were added to the appropriate experimental solutions at a hematocrit of $0.2 \%$ or less. After a 15-minute period of equilibration, samples were taken hourly over a 3-hour period. The samples were treated as described above for sodium outflux studies, and calculations were performed in a similar fashion. Potassium outflux (millimoles per liter red cells per hour) was obtained by multiplying the value so obtained by the intracellular potassium concentration (millimoles per liter red cells). The "rate constant" for potassium outflux, ${ }^{\circ} \mathbf{k}_{\mathrm{K}}$ (millimoles per liter red cells per hour per millimole per liter $\mathbf{K}_{\mathbf{i}}$ ), was then calculated by dividing the value for the potassium outflux by the value for the intracellular potassium concentration expressed as millimoles per liter cell water.

Intracellular electrolyte concentrations. Intracellular sodium and potassium concentrations were estimated by determining sodium, potassium, and hemoglobin concentrations in a hemolysate of cells that had been washed three times in isosmotic $\mathrm{MgCl}_{\mathbf{2}}$ solution. Hematocrit and hemoglobin concentration were also determined in a separate suspension of cells. Electrolyte concentration in millimoles per liter red cells was calculated from the relation,

$$
\left[\mathrm{Na}_{c}\right]\left(\text { or }\left[\mathrm{K}_{\mathrm{c}}\right]\right)=\frac{\left[\mathrm{Na}_{h}\right]\left(\text { or }\left[\mathrm{K}_{\mathrm{h}}\right]\right) \times \mathrm{Hgb}_{\mathrm{s}} \times 10}{\mathrm{Hgb}_{\mathrm{h}} \times \mathrm{Hct}_{\mathrm{s}}},
$$

where $\left[\mathrm{Na}_{c}\right]$ or $\left[\mathrm{K}_{c}\right]$ is the sodium or potassium concentration in millimoles per liter red blood cells, $\left[\mathrm{Na}_{h}\right]$ or $\left[\mathrm{K}_{\mathrm{h}}\right]$ is the sodium or potassium concentration in the hemolysate in millimoles per liter, $\mathrm{Hgb}_{h}$ is the hemolysate 


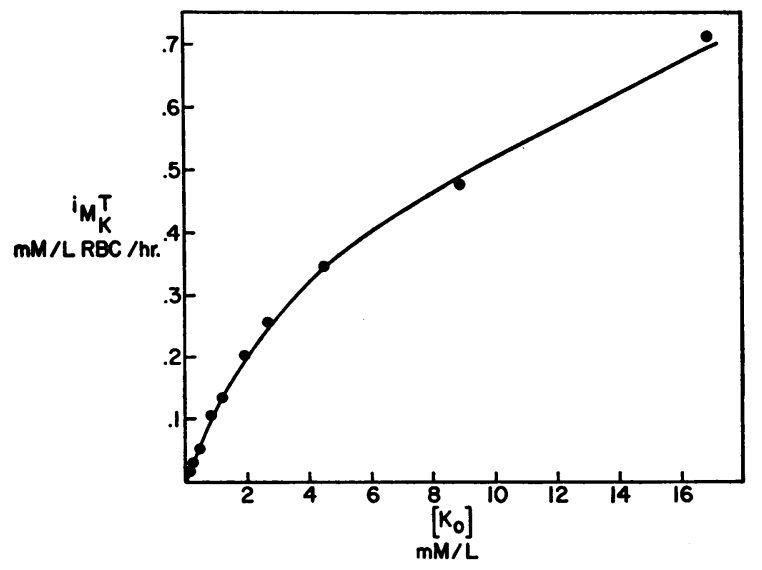

Fig. 1. Potassium influX, ${ }^{i} \mathbf{M}_{\mathbf{K}^{\mathbf{T}}}$, vs. EXTRACEllular POTASSIUM CONCENTRATION, [ $\left.\mathrm{K}_{\mathbf{0}}\right]$, IN THE PRESENCE OF $10^{-4} \mathrm{M}$ STROPHANTHIDIN. The cells were drawn fresh and used without preincubation. The solutions in which the measurements were made contained (mmoles per $\mathrm{L}$ ) $\mathrm{Na}^{+}$, $129 ; \mathrm{Cl}^{-}, 142 ; \mathrm{PO}_{4}, 1.2$; glycylglycine, $33 \rightarrow 27 ; \mathrm{Mg}^{++}$, $15 \rightarrow 5 ; \mathrm{K}^{+}, 0 \rightarrow 17$; glucose, 9 ; and ethanol, $1 \% \mathrm{vol} / \mathrm{vol}$. As the concentration of potassium decreases, the concentrations of glycylglycine and of magnesium increase.

hemoglobin concentration in grams per $100 \mathrm{ml}, \mathrm{Hgb}_{\mathrm{s}}$ is the hemoglobin concentration in the suspension in grams per $100 \mathrm{ml}$, and $\mathrm{Hct}_{\mathrm{s}}$ is the hematocrit of the suspension in milliliters cells per $100 \mathrm{ml}$ suspension.

Electrolyte concentrations were estimated with the Baird DB 4 flame photometer. Freezing point determinations were made with the Fiske osmometer. Counting was performed by the Packard Autogamma; in general 10,000 counts was accumulated, although at times it was not possible to accumulate this many. ${ }^{42} \mathrm{~K}$ and ${ }^{24} \mathrm{Na}$ were obtained commercially as the chlorides. ${ }^{2}$

Determination of the passive potassium influx. To estimate the active potassium influx from the unidirectional flux studies, one must determine the total potassium influx and subtract from it a value for the passive potassium influx. Shaw (1) and Glynn (2) have shown that the potassium influx may be divided into a saturable active component and a passive component that is linear with extracellular potassium concentration. If this passive process conforms to the flux ratio equation (9), and if penetrating anions are at thermodynamic equilibrium, one may calculate the "rate constant" for passive influx $\left({ }^{i} k_{K}{ }^{L}\right)$ from the relation $(2,10)$,

$$
{ }^{i} k_{K}{ }^{L}=\frac{{ }^{o} \mathbf{M K}_{K}{ }^{L}\left[\mathrm{Cl}_{\mathrm{o}}\right]}{\left[\mathrm{K}_{\mathrm{i}}\right]\left[\mathrm{Cl}_{\mathrm{i}}\right]}
$$

where $\left[\mathrm{K}_{\mathbf{i}}\right]$ is intracellular potassium concentration, $\left[\mathrm{Cl}_{\mathbf{i}}\right]$ is intracellular chloride concentration, $\left[\mathrm{Cl}_{0}\right]$ is extracellular chloride concentration, and ${ }^{\circ} \mathbf{M}_{\mathbf{K}}{ }^{L}$ is potassium outflux. Assuming a value of ${ }^{\circ} \mathrm{M}_{\mathrm{K}}{ }^{* \mathrm{~L}}$ of $1.6 \mathrm{mmoles}$ per $\mathrm{L}$ red cells per hour (2), a value of $\left[\mathrm{K}_{\mathrm{i}}\right]$ of 140 mmoles per $\mathrm{L}$ red cell water, and a value of $\left[\mathrm{Cl}_{0}\right] /\left[\mathrm{Cl}_{\mathrm{i}}\right]$ of 1.4 , one may obtain a

2 Iso Serve, Cambridge, Mass. value of ${ }^{i} k_{K}{ }^{L}$ of 0.016 mmole per $L$ red cells per hour per mmole per $\mathrm{L} \mathrm{K}_{\mathrm{o}}$. Therefore, it might be required that any estimate of passive potassium influx yield values that are linear with extracellular potassium concentration (i.e., ${ }^{i} \mathbf{M}_{K}{ }^{L}={ }^{i} k_{K}{ }^{L}\left[K_{0}\right]$ ), with ${ }^{i} k_{K}{ }^{L}$ of the order of magnitude of 0.016 mmole per $\mathrm{L}$ red cells per hour per mmole per $\mathrm{L} \mathrm{K}_{\mathrm{o}}$.

Schatzman (11) has shown that the cardiac glycosides and aglycones inhibit the active movements of sodium and potassium in cold stored red cells, and these drugs have been used to separate the active fluxes of potassium and sodium from the passive fluxes. We have utilized the aglycone strophanthidin; maximal inhibition in ATP-rich red cells under the circumstances we utilized is obtained at a final strophanthidin concentration of $10^{-5}$ mole per $\mathrm{L}$ at an extracellular potassium concentration of 16 mmoles per L. In all studies reported here, strophanthidin, when present, is at a final concentration of $10^{-4}$ mole per $\mathrm{L}$. Figure 1 represents a plot of potassium influx vs. extracellular potassium concentration in ATP-rich cells in the presence of $10^{-4} \mathrm{M}$ strophanthidin; the experiment is typical of six determinations. It does not conform to the requirement that the influx be proportional to the external potassium concentration; rather, the influx rises more rapidly at low extracellular potassium concentrations than at high, i.e., the system demonstrates saturation kinetics. Similar results were obtained by Glynn (12) utilizing scillaren. The simplest explanation for this behavior is that the aglycone does not completely inhibit the active influx. Figure 2 represents data obtained with depleted cells with strophanthidin at $10^{-4}$ mole per $\mathrm{L}$ in the solution in which the influx was measured. The linear relation of potassium influx to external potassium concentration is apparent. The mean value for ${ }^{i} k_{K}{ }^{L}$ from 15 such determinations was 0.018 mmole per $\mathrm{L}$ red cells per hour per mmole per $\mathrm{L} \mathrm{K}_{\mathrm{o}}$ (SEM 0.001), in fair agreement with the predicted value of 0.016 mmole per $\mathrm{L}$ red cells per hour per mmole per $\mathrm{L} \mathrm{K}_{\mathrm{o}}$.

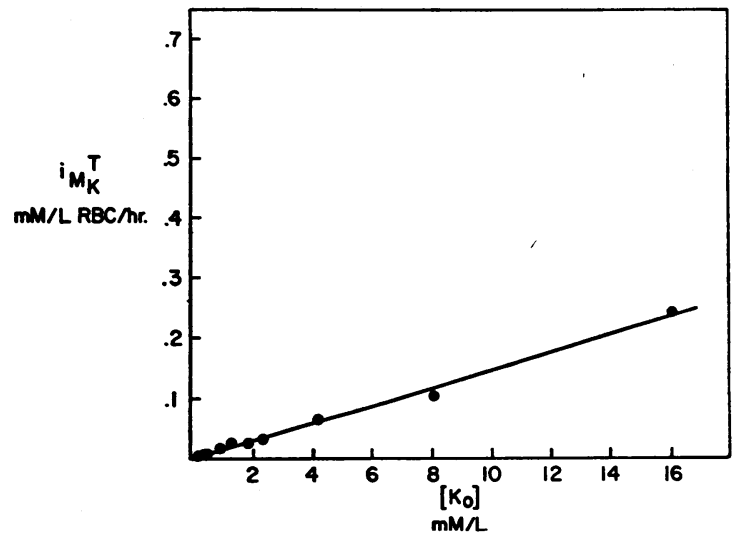

Fig. 2. Potassium influx, ${ }^{i} \mathbf{M}_{\mathbf{K}^{T}}$, vs. extracellular POTASSIUM CONCENTRATION, $\left[\mathrm{K}_{0}\right]$, IN CELLS THAT HAD BEEN DEPLETED OF ATP OVER AN 18-HOUR PERIOD BEFORE MEASUREMENTS WERE MADE. The curve is: ${ }^{\mathrm{i}} \mathrm{M}_{\mathrm{K}}{ }^{\mathrm{T}}=-0.00046$ $+0.0147\left[\mathrm{~K}_{0}\right] ; \mathrm{r}=0.998$. The solutions used were the same as those described under Figure 1 except that strophanthidin was present at $10^{-4}$ mole per $\mathrm{L}$. 
That depletion alone does not completely inhibit the active potassium influx is shown in Table $I$, in which values for potassium influx in repleted cells, depleted cells, and depleted cells to which strophanthidin was added are compared.

Measurements of potassium outflux were made under conditions as close as possible to those under which the measurements of passive potassium influx were made. The value for the "rate constant" for potassium outflux, ${ }^{\circ} \mathrm{kK}_{\mathrm{K}} \mathrm{L}$, so determined was 0.013 mmole per $\mathrm{L}$ red cells per hour per mmole per $\mathrm{L} \mathrm{K}_{\mathbf{i}}$ (SEM 0.0005 , four determinations); with the flux ratio equation and the observed value for ${ }^{i} k_{K}{ }^{L}(.018$ mmole per $L$ red cells per hour per mmole per $\mathrm{L} \mathrm{K}_{\mathrm{o}}$ ), the predicted value for ${ }^{\circ} \mathrm{k}_{\mathrm{K}}{ }^{\mathrm{L}}$ is 0.013 mmole per $\mathrm{L}$ red cells per hour per mmole per $\mathrm{L} \mathrm{K}_{\mathrm{i}}$.

The value for ${ }^{i} \mathbf{k}_{K}{ }^{\mathbf{l}}$ obtained here is considerably higher than the value of approximately 0.006 mmole per $\mathrm{L}$ red cells per hour per mmole per $\mathrm{L} \mathrm{K}_{\mathrm{o}}$ obtained by Glynn (2) from the flat portion of the curve of potassium influx vs. extracellular potassium concentration. Two explanations for this discrepancy might be offered. In Glynn's measurements, extracellular potassium was raised by lowering extracellular sodium; it is possible that the lower extracellular sodium may have altered membrane permeability to potassium. Secondly, in our experiments the measurements were made after 18 hours of incubation in the absence of glucose, whereas Glynn's measurements were made in fresh cells; either the prolonged preincubation or the depletion of energy stores may have led to increased membrane permeability to potassium.

Values for active potassium influx reported here were obtained by subtracting values for passive potassium influx obtained in depleted cells exposed to $10^{-4} \mathrm{M}$ strophanthidin from values for total potassium influx obtained in repleted cells not exposed to strophanthidin.

Theoretical. The results to be described below may be interpreted in terms of a model in which potassium ions are required at two "sites" in the active transport system before either active potassium influx or that portion of the sodium outflux that is dependent on the presence of external potassium can occur. Such a system may be represented as:

$$
\begin{aligned}
X+\mathrm{K}_{0} \underset{\mathrm{k}_{2}}{\stackrel{\mathrm{k}_{1}}{\rightleftharpoons}} X \mathrm{~K} \\
X \mathrm{~K}+\mathrm{K}_{0} \underset{\mathrm{k}_{4}}{\stackrel{\mathrm{k}_{3}}{\rightleftharpoons}} X 2 \mathrm{~K} \\
X 2 \mathrm{~K} \stackrel{\mathrm{k}_{5}}{\rightleftharpoons} X \mathrm{~K}+\mathrm{K}_{\mathrm{i}}
\end{aligned}
$$

where $X$ is a component (or interrelated components) of the transport system, present in limited quantities, and requiring the presence of two potassium ions; $\mathrm{K}_{\mathrm{o}}$ is extracellular potassium; and $K_{i}$ is intracellular potassium. ${ }^{i} \mathrm{M}_{\mathrm{K}}{ }^{\mathrm{P}}$ (active potassium influx) $=\mathrm{k}_{5} X 2 \mathrm{~K} . \quad \mathrm{k}_{5}$ is obviously a complicated term that depends on the rapidity of the transfer of the complex from the outer to the inner surface of the membrane, the velocity of dissociation of potassium from the complex at the inner surface, and the rapidity with which $X$ again becomes receptive to combination
TABLE I

Potassium influx in the presence of $1.8 \mathrm{mM}$ potassium*

\begin{tabular}{lcc}
\hline \hline $\begin{array}{c}\text { Repleted cells no } \\
\text { strophanthidin }\end{array}$ & $\begin{array}{c}\text { Depleted cells no } \\
\text { strophanthidin }\end{array}$ & $\begin{array}{c}\text { Depleted cells stro- } \\
\text { phanthidin 10-4M }\end{array}$ \\
\hline \multicolumn{3}{c}{ mmoles $/ L$ red cells/hour } \\
1.03 (SEM 0.042) & 0.159 (SEM 0.007) $\quad 0.037$ (SEM 0.006)
\end{tabular}

* Means of six determinations. Solution contained (mmoles per $\mathrm{L}$ ) $\mathrm{Na}^{+}, 129 ; \mathrm{Cl}^{-}, 130 ; \mathrm{PO}_{4}, 1.2 ;$ glycylglycine, $32 ; \mathrm{Mg}^{++}, 14 ; \mathrm{K}^{+}, 1.8$; glucose, 9; and ethanol, $1 \%$ vol/vol.

with $\mathrm{K}_{\mathrm{o}}$ at the outer surface. Assuming that $\mathrm{k}_{5}$ is so much less than the other constants that reactions 1 and 2 may be considered at equilibrium, one may obtain:

$$
{ }^{i} \mathbf{M}_{\mathbf{K}}{ }^{P}=\frac{a}{1+\frac{b}{\left[\mathrm{~K}_{0}\right]}+\frac{c}{\left[\mathrm{~K}_{0}\right]^{2}}}
$$

where $a, b$, and $c$ are constants.

If Equation 4 is written in reciprocal form, the following relation is obtained:

$$
\frac{1}{\mathrm{i}_{\mathrm{K}^{\mathrm{P}}}}=\frac{1}{\mathrm{a}}+\frac{\mathrm{b}}{\mathrm{a}} \frac{1}{\left[\mathrm{~K}_{\mathrm{o}}\right]}+\frac{\mathrm{c}}{\mathrm{a}} \frac{1}{\left[\mathrm{~K}_{\mathrm{o}}\right]^{2}} .
$$

Equations 4 and 5 are similar to the corresponding equations obtained from the Michaelis-Menten model in that saturation kinetics will be demonstrated. They differ, however, in that a plot of ${ }^{i} \mathbf{M}_{\mathbf{K}}{ }^{P}$ vs. $\left[K_{0}\right]$ will generate a sigmoid rather than a hyperbolic curve, and a plot of $1 /{ }^{i} M_{K}{ }^{P}$ vs. $1 /\left[K_{0}\right]$ will generate a parabola rather than a straight line.

Let us assume that there is a substance $I$, different from potassium, which is transported by the same system that transports potassium. Qualitatively, one might expect that, if potassium influx is measured, the substance $I$ will behave as a competitive inhibitor, i.e., as the concentration of $I$ increases at constant external potassium concentration, ${ }^{i} \mathbf{M}_{\mathbf{K}}{ }^{\mathrm{P}}$ will decrease. However, at very low potassium concentrations, $I$ may substitute for potassium at one of the sites and the potassium influx might increase at low external concentrations of $I$. The system may be represented as :

$$
\begin{aligned}
& X+\mathrm{K}_{\mathrm{o}} \underset{\mathrm{k}_{2}}{\stackrel{\mathrm{k}_{1}}{\rightleftharpoons}} X \mathrm{~K} \\
& X+I_{0} \underset{\mathrm{k}_{4}}{\stackrel{\mathrm{k}_{3}}{\rightleftharpoons}} X I \\
& X^{\mathrm{T}}=X \mathrm{~K}+X I \\
& X^{\mathrm{T}}+\mathrm{K}_{\mathrm{o}} \underset{\mathrm{k}_{6}}{\stackrel{\mathrm{k}_{5}}{\rightleftharpoons}} X^{\mathrm{T}} \mathrm{K} \\
& X^{\mathrm{T}}+I_{\mathrm{o}} \underset{\mathrm{k}_{8}}{\stackrel{\mathrm{k}_{7}}{\rightleftharpoons}} X^{\mathrm{T}} I \\
& X^{\mathrm{T}} \mathrm{K} \stackrel{\mathrm{k}_{\boldsymbol{9}}}{\longrightarrow} X^{\mathrm{T}}+\mathrm{K}_{\mathrm{i}} \\
& X^{\mathrm{T}} I \stackrel{\mathrm{k}_{10}}{\longrightarrow} X^{\mathrm{T}}+I_{\mathrm{i}} .
\end{aligned}
$$


Again assuming that $k_{9}$ and $k_{10}$ are considerably less than the other rate constants so that the system! is at equilibrium, one may obtain:

$$
{ }^{i} \mathbf{M}_{\mathbf{K}^{P}}{ }^{P}=\frac{\mathrm{a}^{\prime}}{1+\frac{\mathrm{b}^{\prime}}{\left[\mathrm{K}_{\mathrm{o}}\right]}+\mathrm{c}^{\prime} \frac{\left[I_{0}\right]}{\left[\mathrm{K}_{\mathrm{o}}\right]}+\frac{\mathrm{d}^{\prime}}{\mathrm{e}^{\prime}\left[\mathrm{K}_{\mathrm{o}}\right]^{2}+\mathrm{f}^{\prime}\left[\mathrm{K}_{\mathrm{o}}\right]\left[I_{\mathrm{o}}\right]}},
$$

or:

$$
\begin{aligned}
\frac{1}{{ }^{i} \mathbf{K}^{P}}=\frac{1}{\mathrm{a}^{\prime}}+\frac{\mathrm{b}^{\prime}}{\mathrm{a}^{\prime}} \frac{1}{\left[\mathrm{~K}_{\mathrm{o}}\right]}+ & \frac{\mathrm{c}^{\prime}}{\mathrm{a}^{\prime}} \frac{\left[I_{0}\right]}{\left[\mathrm{K}_{\mathrm{o}}\right]} \\
& +\frac{\mathrm{d}^{\prime}}{\mathrm{a}^{\prime}} \frac{1}{\mathrm{e}^{\prime}\left[\mathrm{K}_{\mathrm{o}}\right]^{2}+\mathrm{f}^{\prime}\left[\mathrm{K}_{\mathrm{o}}\right]\left[I_{\mathrm{o}}\right]}
\end{aligned}
$$

where $\mathrm{a}^{\prime}, \mathrm{b}^{\prime}, \mathrm{c}^{\prime}, \mathrm{d}^{\prime}, \mathrm{e}^{\prime}$, and $\mathrm{f}^{\prime}$ are constants and $\left[I_{\mathrm{o}}\right]$ is the concentration of the substance $I$. If $\left[\mathrm{K}_{\circ}\right]$ is held constant, one may obtain:

$$
{ }^{\mathrm{i}} \mathrm{M}_{\mathrm{K}} \mathrm{P}=\frac{1}{\mathrm{k}_{1}+\mathrm{k}_{2}\left[I_{\mathrm{o}}\right]+\frac{1}{\mathrm{k}_{3}+\mathrm{k}_{4}\left[I_{\mathrm{o}}\right]}}
$$

and :

$$
\frac{1}{{ }^{\mathrm{i}} \mathbf{M}_{\mathbf{K}} \mathbf{P}}=\mathrm{k}_{1}+\mathrm{k}_{2}\left[I_{\mathrm{o}}\right]+\frac{1}{\mathrm{k}_{3}+\mathrm{k}_{4}\left[I_{\mathrm{o}}\right]},
$$

where $k_{1}, k_{2}, k_{3}$, and $k_{4}$ are constants. From Equation 15 it can be seen that as $\left[I_{0}\right]$ increases, ${ }^{i} \mathrm{M}_{\mathrm{K}}{ }^{\mathrm{P}}$ will at first increase and then decrease. In the corresponding MichaelisMenten system, the velocity of the process continuously decreases with increasing concentration of inhibitor.

If a constant value of $\left[I_{0}\right]$ is chosen and $\left[\mathrm{K}_{0}\right]$ is varied, comparison of Equation 12 with Equation 4 will enable one to predict that, if $\left[I_{0}\right]$ is sufficiently high, the sigmoid character of the plot of ${ }^{i} \mathbf{M}_{K}{ }^{P}$ against $\left[K_{0}\right]$ may be elimi-

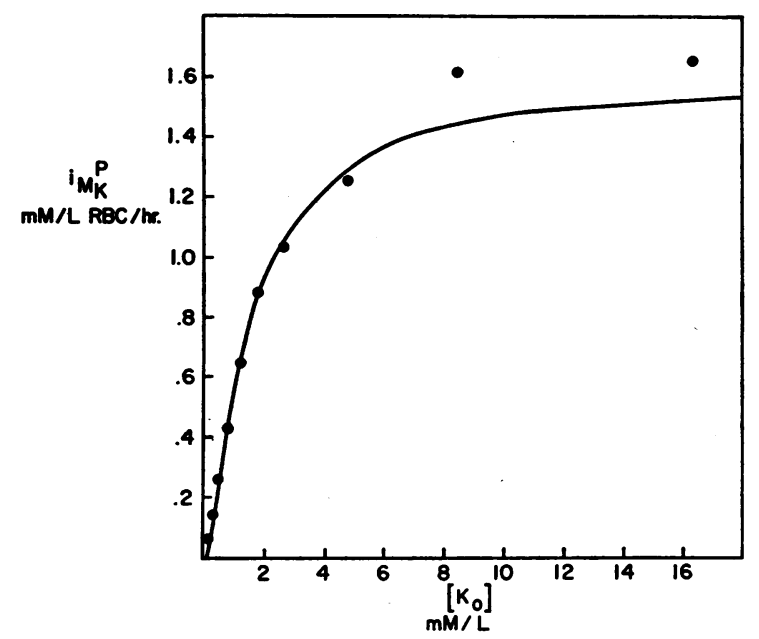

Fig. 3. ACtive POTASSIUM INFLUX, ${ }^{i} \mathbf{M}_{\mathbf{K}}{ }^{P}$, vS. EXTRACEllular potassium concentration, $\left[\mathrm{K}_{\circ}\right]$. The curve is :

$$
{ }^{\mathrm{i}} \mathrm{M}_{\mathrm{K}} \mathrm{P}=\frac{1.66}{1+\frac{1.31}{\left[\mathrm{~K}_{0}\right]}+\frac{0.55}{\left[\mathrm{~K}_{0}\right]^{2}}}
$$

$\rho$ (index of curvilinear correlation) $=0.986$. The solutions in which the measurements were made were the same as those described in Figure 1.

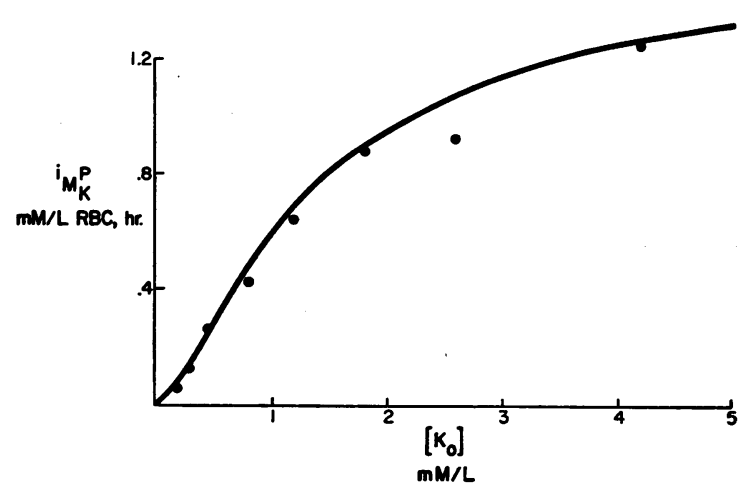

Fig. 3A. ACtive potassium INFLUx, ${ }^{i} \mathrm{M}_{\mathrm{K}}{ }^{\mathrm{P}}$, vs. EXtraCELLULAR CONCENTRATION OF POTASSIUM, $\left[\mathrm{K}_{0}\right]$. In this plot the same data are used as in Figure 3, but the horizontal axis has been expanded to demonstrate the sigmoid character of the curve. Values for external potassium concentration in excess of 5 mmoles per $\mathrm{L}$ have been eliminated.

nated. Comparison of Equation 13 with Equation 5 similarly enables one to predict that a plot of $1 /{ }^{i} M_{K^{P}}$ vs. $1 /\left[K_{0}\right]$ may be converted from a parabola to a straight line.

The behavior of the "rate constant" for total potassium influx, ${ }^{i} \mathbf{k}_{\mathbf{K}}{ }^{\mathrm{T}}$, with varying extracellular potassium concentrations will be markedly different in a system displaying this type of kinetics from its behavior in a system displaying classic Michaelis-Menten kinetics. If the active transport system of the red blood cell demonstrated classic Michaelis-Menten kinetics, the total potassium influx, ${ }^{i} M_{K}{ }^{T}$, would be related to the external potassium concentration by the relation,

$$
{ }^{i} M_{K}{ }^{T}=\frac{a}{1+\frac{b}{\left[K_{0}\right]}}+{ }^{i} k_{K}{ }^{L}\left[K_{0}\right],
$$

where ${ }^{i} k_{K}{ }^{L}$ is the "rate constant" for passive potassium influx and the other terms have their usual significance. The right-hand side of the equation consists of a term for the active potassium influx plus a term for the passive potassium influx. If both sides are divided by $\left[\mathrm{K}_{0}\right]$,

$$
\frac{{ }^{i} \mathbf{M}_{K^{T}}}{\left[K_{0}\right]}={ }^{i} k_{K^{T}}=\frac{a}{\left[K_{0}\right]+b}+{ }^{i} k_{K^{L}} \text {. }
$$

From this equation it can be seen that ${ }^{i} \mathbf{k}_{K}{ }^{T}$, the "rate constant" for total potassium influx, will continuously decrease as $\left[\mathrm{K}_{\mathrm{o}}\right]$ increases. In the model described above, the relation corresponding to Equation 17 is:

$$
{ }^{i} \mathbf{M}_{K^{T}}=\frac{a}{1+\frac{b}{\left[\mathrm{~K}_{\mathrm{o}}\right]}+\frac{\mathrm{c}}{\left[\mathrm{K}_{\mathrm{o}}\right]^{2}}}+{ }^{i} \mathrm{k}_{\mathrm{K}} \mathrm{L}\left[\mathrm{K}_{\mathrm{o}}\right] .
$$

Again if both sides are divided by $\left[\mathrm{K}_{\mathrm{o}}\right]$,

$$
\frac{{ }^{i} \mathbf{M}_{\mathbf{K}} \mathbf{T}}{\left[\mathrm{K}_{0}\right]}={ }^{i} \mathbf{k}_{\mathbf{K}^{T}}=\frac{a}{\left[\mathrm{~K}_{0}\right]+b+\frac{c}{\left[\mathrm{~K}_{0}\right]}}+{ }^{i} \mathbf{k}_{\mathbf{K}^{\mathrm{L}}} \text {. }
$$

From this equation it can be seen that ${ }^{i} \mathrm{k}_{\mathrm{K}}{ }^{\mathrm{T}}$ will at first increase as $\left[K_{0}\right]$ increases $\left(\left[K_{0}\right]<\sqrt{ } c\right)$ and then decrease as $\left[K_{0}\right]$ becomes greater than $\sqrt{ } \mathbf{c}$. 


\section{Results}

The relation between active potassium influx and external potassium concentration. Figures 3 and $3 \mathrm{~A}^{3}$ represent a plot of active potassium influx vs. external potassium concentration, and Figure 4 represents a plot of the reciprocal of the active potassium influx vs. the reciprocal of the external potassium concentration from a typical experiment; 15 similar experiments were performed with similar results. The data are well described

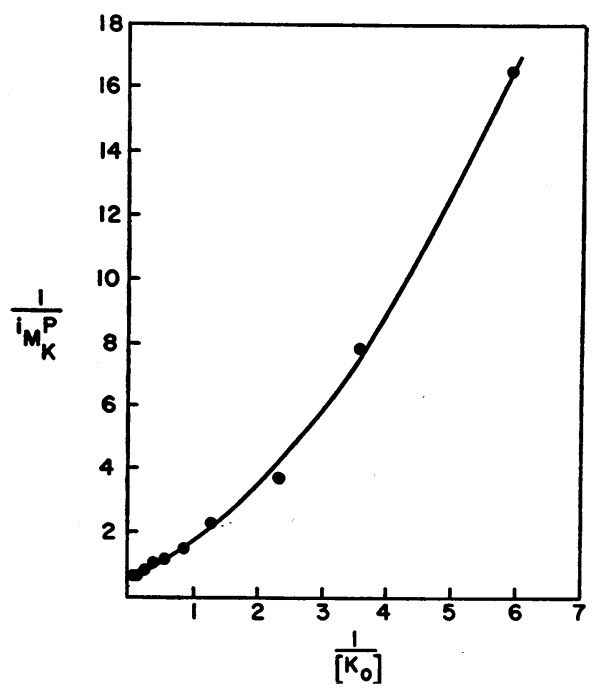

Fig. 4. THE RECIPROCAL OF THE ACTIVE POTASSIUM INFLUX, $1 /{ }^{i} \mathbf{M K}_{\mathbf{K}}{ }^{\mathrm{P}}$, VS. THE RECIPROCAL OF THE EXTRACELLULAR POTASSIUM CONCENTRATION, $1 /\left[\mathrm{K}_{\mathrm{o}}\right]$ FROM THE SAME DATA AS THOSE PLOTTED IN Figure 3 . The curve is:

$$
\frac{1}{\mathrm{i}_{\mathrm{K}}^{\mathrm{P}}}=\frac{1}{1.66}+\frac{1.31}{1.66} \frac{1}{\left[\mathrm{~K}_{\mathrm{o}}\right]}+\frac{0.55}{1.66} \frac{1}{\left[\mathrm{~K}_{\mathrm{o}}\right]^{2}} \text {. }
$$

$\rho=0.999$.

by equations of the form of Equations 4 and 5 ; the equations were fitted to the data by the method of least squares. Similar plots of data from a system displaying Michaelis-Menten kinetics would yield a continuously rising curve rather than a sigmoid curve in the plot of Figure 3 and Figure $3 \mathrm{~A}$, and a straight line rather than a parabola in the plot of Figure 4. Mean values for the constants a, b, and c of Equation 4 obtained from 15 experiments are given in Table II.

\footnotetext{
${ }^{3}$ To demonstrate more clearly the sigmoid character of the curve, Figure 3A employs the same data as Figure 3, but the horizontal axis has been expanded and eliminates values of $\left[K_{\circ}\right]$ greater than 5 mmoles per $L$.
}

TABLE II

Mean values for the constants $a, b$, and $c$ from 15 experiments*

\begin{tabular}{ccc}
\hline \hline $\mathrm{a}$ & $\mathrm{b}$ & $\mathrm{c}$ \\
\hline $1.94(\mathrm{SEM} 0.09)$ & $1.55(\mathrm{SEM} 0.15)$ & 0.57 (SEM 0.05)
\end{tabular}

* The constants were evaluated by fitting a curve of the form of Equation 5 to the data of each experiment by the method of least squares.

Since these experiments were performed with depleted cells and depleted-repleted cells, and since $\mathrm{KCl}$ solution was replaced by a solution containing $80 \% \mathrm{MgCl}_{2}$ solution and $20 \%$ glycylglycine- $\mathrm{MgCO}_{3}$ buffer solution, it might be argued that the deviation from Michaelis-Menten kinetics described here was due either to the presence of increasing concentrations of magnesium or to the use of depleted-repleted cells. To eliminate these possibilities, we measured potassium influx in freshly drawn cells suspended in an incubation medium containing only sodium and potassium as cations, the potassium in the flasks at low concentration being replaced by sodium. In Table III the results of the experiment on three specimens are listed. The data demonstrate that the "rate constant" for total potassium influx, ${ }^{i} \mathbf{k}_{\mathrm{K}}{ }^{\mathrm{T}}$, increases as the external potassium concentration increases from 0.24 to 1.30 mmoles per $\mathrm{L}$. This is in accordance with the prediction made from Equation 20, but not that made from Equation 18. Therefore, the behavior of fresh cells in the absence of magnesium is as would be predicted from the model presented in the theoretical section, but not as would be predicted by the Michaelis-Menten model.

The potassium-activated sodium outflux. The form of the relation between the potassium-dependent component of the sodium outflux and the extracellular potassium concentration is de-

TABLE III

The "rate constant" for total potassium influx measured at two concentrations of extracellular potassium $\left[K_{0}\right]$ in fresh cells in the absence of magnesium*

\begin{tabular}{ccc}
\hline \hline Sample & {$\left[\mathrm{K}_{0}\right]=0.24$} & {$\left[\mathrm{~K}_{0}\right]=1.30$} \\
\hline & mmole $/ L$ red cells $/$ hour $/$ mmole $/ L K_{\circ}$ \\
1 & 0.25 & 0.57 \\
2 & 0.25 & 0.48 \\
3 & 0.49 & 0.83
\end{tabular}

* Solution contained (mmoles per $\mathrm{L}$ ) $\mathrm{Na}^{+}, 159 ; \mathrm{Cl}^{-}, 154$; $\mathrm{PO}_{4}, 12.1$; glucose, 9 ; and ethanol, $1 \% \mathrm{vol} / \mathrm{vol}$. 


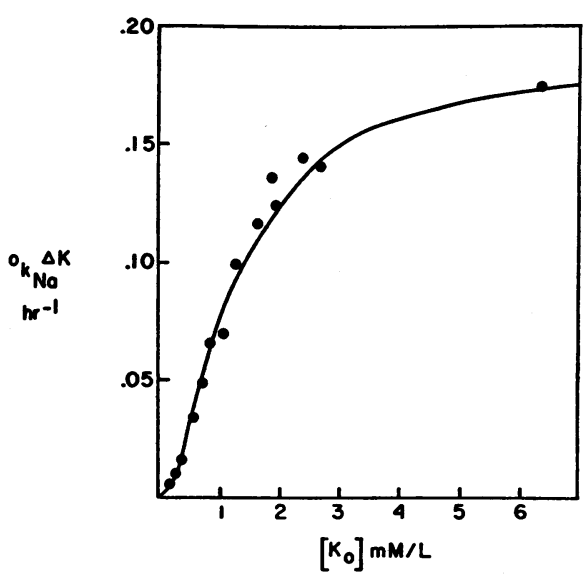

Fig. 5. The "RATE CONSTANT" fOR the POtAssiumDEPENDENT COMPONENT OF THE SODIUM OUTFLUX, ${ }^{\circ} \mathrm{k}_{\mathrm{Na}} \Delta \mathrm{K}$, vS. THE EXTRACELLULAR POTASSIUM CONCENTRATION, [Ko]. The curve is :

$\rho=0.996$

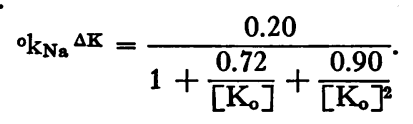

The solutions in which the measurements were made contained (mmoles per L) $\mathrm{Na}^{+}, 137 ; \mathrm{Cl}^{-}, 142 ; \mathrm{PO}_{4}, 1.3$; glycylglycine, $31 \rightarrow 29 ; \mathrm{Mg}^{++}, 10 \rightarrow 6 ; \mathrm{K}^{+}, 0 \rightarrow 6.4 ;$ glucose, 9. As the potassium concentration increases, the concentrations of glycylglycine and of magnesium decrease.

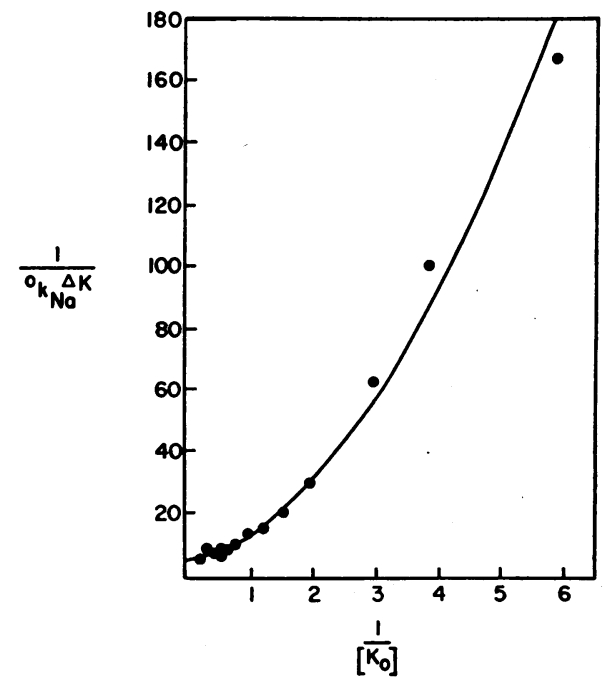

Fig. 6. The reciprocal of the "rate constant" FOR THE POTASSIUM-DEPENDENT COMPONENT OF THE SODIUM OUTFLUX, $1 /{ }^{\circ} \mathrm{K}_{\mathrm{Na}} \Delta \mathrm{K}$, VS. THE RECIPROCAL OF THE EXTRACELlular POTASSIUM CONCENTRATION, 1/[K, FROM THE DATA PLOTTED IN Figure 5. The curve is:

$$
\frac{1}{{ }^{0 \mathrm{k}_{\mathrm{N} \mathrm{a}} \Delta \mathrm{K}}}=\frac{1}{0.20}+\frac{0.72}{0.20} \frac{1}{\left[\mathrm{~K}_{\mathrm{o}}\right]}+\frac{0.90}{0.20} \frac{1}{\left[\mathrm{~K}_{\circ}\right]^{2}} \text {. }
$$

$\rho=0.990$. picted in Figure 5; the experiment was performed three times with similar results. The quantity on the abscissa, ${ }^{\circ} \mathbf{k}_{\mathrm{Na}} \Delta \mathbf{K}$, is the difference between the "rate constant" for sodium outflux measured at a particular extracellular potassium concentration and the "rate constant" for sodium outflux measured in the absence of extracellular potassium. The data are well described by a curve of the form,

$$
{ }^{\circ} \mathrm{k}_{\mathrm{Na}} \Delta \mathrm{K}=\frac{\mathrm{a}}{1+\frac{\mathrm{b}}{\left[\mathrm{K}_{\mathrm{o}}\right]}+\frac{\mathrm{c}}{\left[\mathrm{K}_{\mathrm{o}}\right]^{2}}} .
$$

The curve was obtained from the data by the method of least squares. Figure 6 demonstrates a reciprocal plot of the same data, and again the form of the curve that describes the data is parabolic, and of the form of the reciprocal of Equation 21.

The active potassium influx in the presence of rubidium, cesium, and lithium. Figure 7 represents a plot of the reciprocal of the active potassium influx vs. the reciprocal of the extracellular potassium concentration from an experiment in which the active potassium influx was measured in the presence and absence of $2.5 \mathrm{mM}$ rubidium at varying extracellular potassium concentrations; it is typical of three experiments so performed. The curve in the absence of rubidium is again a parabola, but in the presence of 2.5 $\mathrm{mM}$ extracellular rubidium it has been converted to a straight line; the curves were fitted from the data by the method of least squares. If the results of this experiment are plotted directly as active potassium influx vs. extracellular potassium concentration, the curve in the absence of rubidium is again sigmoid, whereas that in the presence of $2.5 \mathrm{mM}$ extracellular rubidium is hyperbolic. Cesium behaves similarly except that the curve of the reciprocal of active potassium influx vs. the reciprocal of the extracellular potassium concentration in the presence of 2.5 $\mathrm{mM}$ extracellular cesium is not completely straight, possibly due to the low affinity of cesium for the transport system.

If extracellular potassium concentration is held constant at a low value and active potassium influx measured at varying extracellular concentrations of inhibitor, where the inhibitor is rubidium, cesium, or lithium, the model predicts that the relation will be of the form of Equation 14 . 


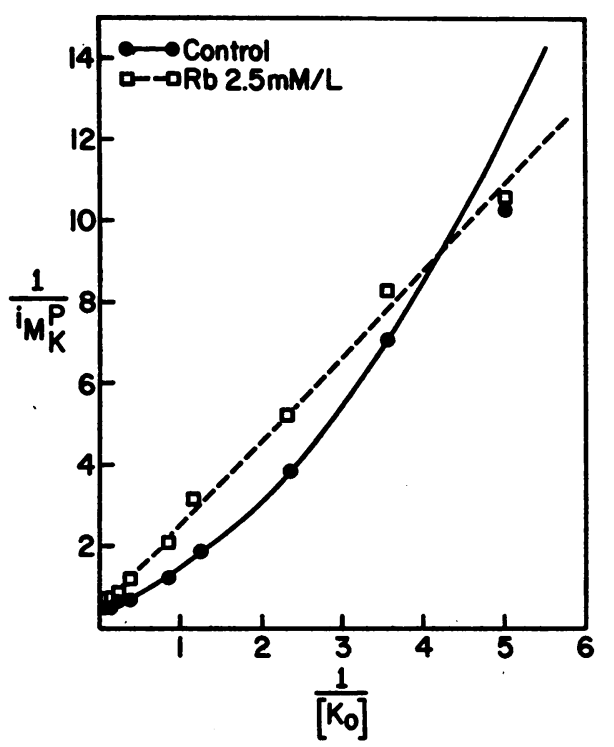

Fig. 7. THE RECIPROCAL OF THE ACTIVE POTASSIUM INFLUX, $1 /{ }^{i} M_{K}{ }^{P}$, VS. THE RECIPROCAL OF THE EXTRACELLULAR POTASSIUM CONCENTRATION, $1 /\left[\mathrm{K}_{0}\right]$, IN THE PRESENCE AND ABSENCE OF 2.5 MMOLES PER L EXTRACELLULAR RUBIDIUM. The curve in the absence of rubidium is:

$$
\frac{1}{\mathrm{i}_{\mathrm{K}^{\mathrm{P}}}}=\frac{1}{2.33}+\frac{1.74}{2.33} \frac{1}{\left[\mathrm{~K}_{\mathrm{o}}\right]}+\frac{0.72}{2.33} \frac{1}{\left[\mathrm{~K}_{\mathrm{o}}\right]^{2}} .
$$

$\rho=0.984$; the curve in the presence of rubidium is:

$$
\frac{1}{\mathrm{i}_{\mathrm{K}^{\mathrm{P}}}}=\frac{1}{2.22}+\frac{4.62}{2.22} \frac{1}{\left[\mathrm{~K}_{\mathrm{o}}\right]} \text {. }
$$

$\mathbf{r}=\mathbf{0 . 9 9}$. The solutions in which the measurements in the absence of rubidium were made contained (mmoles per $\mathrm{L}$ ) $\mathrm{Na}^{+}, 119 ; \mathrm{Cl}^{-}, 142 ; \mathrm{PO}_{4}, 1.2$; glycylglycine, $33 \rightarrow 27 ; \mathrm{Mg}^{++}$, $17 \rightarrow 7 ; \mathrm{K}^{+}, 0 \rightarrow 17$; glucose, 9 ; and ethanol, $1 \%$ vol $/ \mathrm{vol}$. The solutions in which the measurements in the presence of rubidium were made were identical except that they contained (mmoles per L) $\mathrm{Rb}^{+}, 2.5$; glycylglycine, $32 \rightarrow 26$; and $\mathrm{Mg}^{++}, 15 \rightarrow 5$. As the concentration of potassium increases, the concentrations of glycylglycine and of magnesium decrease.

Figure 8 depicts the results of such experiments; it is typical of three such determinations. In each case the active potassium influx at first increased with increasing concentration of inhibitor, and then decreased. The curves are well described by curves of the form of Equation 14; the curves were fit to the data by trial and error. Figure 9 is a plot of the reciprocal of the active potassium influx vs. the extracellular concentration of inhibitor, and again the data are well described by curves of the form of Equation 15. The behavior of the system is what would be predicted on the basis of the model.
The extracellular potassium concentration in the presence of the inhibitors was not measured in these studies, and it might be suggested that the presence of the inhibitor in some way altered the extracellular potassium concentration so as to account for the observed results. Since increases in potassium concentration in this sytem could only have come from the cells, the inhibitor would have had to cause either an increased hemolysis or an increase in potassium outflux to lead to an increased extracellular concentration

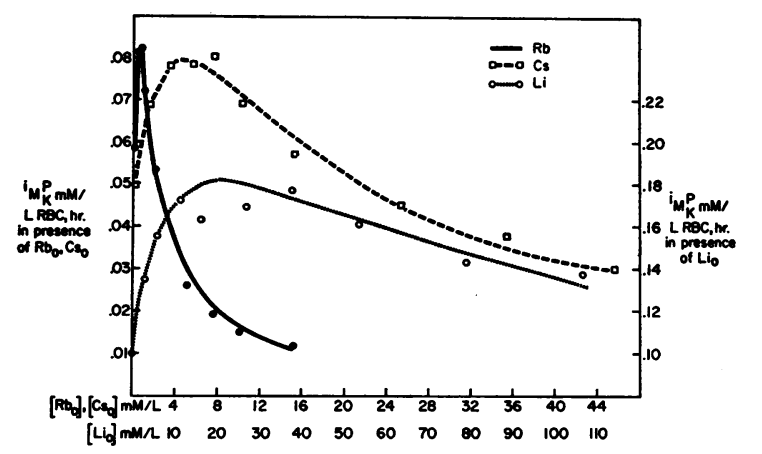

Fig. 8. The active potassium influX, ${ }^{i} \mathbf{M}_{K}{ }^{P}$, vs. THE EXTRACELLULAR CONCENTRATION OF INHIBITOR, [ $\left.I_{0}\right]$ WHERE THE INHIBITOR IS RUBIDIUM, CESIUM, OR LITHIUM. The data for lithium are plotted on different scales from those for rubidium and cesium. For the rubidium experiment the curve is:

$$
{ }^{i} \mathrm{M}_{\mathrm{K}}^{\mathrm{P}}=\frac{1}{4.0+5.55\left[\mathrm{Rb}_{\mathrm{o}}\right]+\frac{1}{0.075+0.23\left[\mathrm{Rb}_{\mathrm{o}}\right]}} .
$$

$\rho=0.994 ;$ for the cesium experiment the curve is :

$$
{ }^{i} \mathrm{M}_{\mathrm{K}} \mathrm{P}=\frac{1}{5.0+0.63\left[\mathrm{Cs}_{\mathrm{o}}\right]+\frac{1}{0.068+0.031\left[\mathrm{Cs}_{\mathrm{o}}\right]}} .
$$

$\rho=0.986$; for the lithium experiment the curve is:

$$
\begin{aligned}
& { }^{i} \mathrm{M}_{\mathrm{K}} \mathrm{P}=\frac{1}{4.2+0.030\left[\mathrm{Li}_{\mathrm{o}}\right]+\frac{1}{0.17+0.056\left[\mathrm{Li}_{\mathrm{o}}\right]}} . \\
& \rho=0.940 \text {. }
\end{aligned}
$$

For the rubidium experiment, the solutions contained (mmoles per $\mathrm{L}$ ) $\mathrm{Na}^{+}, 101 ; \mathrm{Cl}^{-}, 151 ; \mathrm{PO}_{4}, 1.2$; glycylglycine, $36 \rightarrow 30 ; \mathrm{Mg}^{++}, 33 \rightarrow 23 ; \mathrm{K}^{+}, 0.16 ; \mathrm{Rb}^{+}, 0 \rightarrow 15 ;$ glucose, 9; and ethanol, $1 \% \mathrm{vol} / \mathrm{vol}$. For the cesium experiment, the solutions contained (mmoles per $\mathrm{L}$ ) $\mathrm{Na}^{+}, 101 ; \mathrm{Cl}^{-}, 151$; $\mathrm{PO}_{4}, 1.2$; glycylglycine, $36 \rightarrow 20 ; \mathrm{Mg}^{++}, 33 \rightarrow 4 ; \mathrm{K}^{+}, 0.14$; $\mathrm{Cs}^{+}, \mathrm{O} \rightarrow 46$; glucose, 9 ; and ethanol, $1 \% \mathrm{vol} / \mathrm{vol}$. For the lithium experiment, the solutions contained (mmoles per L) $\mathrm{Na}^{+}, 38 ; \mathrm{Cl}^{-}, 148 ; \mathrm{PO}_{4}, 1.2$; glycylglycine, $64 \rightarrow 27$; $\mathrm{Mg}^{++}, 71 \rightarrow 5 ; \mathrm{K}^{+}, 0.13 ; \mathrm{Li}^{+}, 0 \rightarrow 107$; glucose, 9; and ethanol, $1 \% \mathrm{vol} / \mathrm{vol}$. As the concentration of inhibitor increases, the concentrations of glycylglycine and of magnesium decrease. 


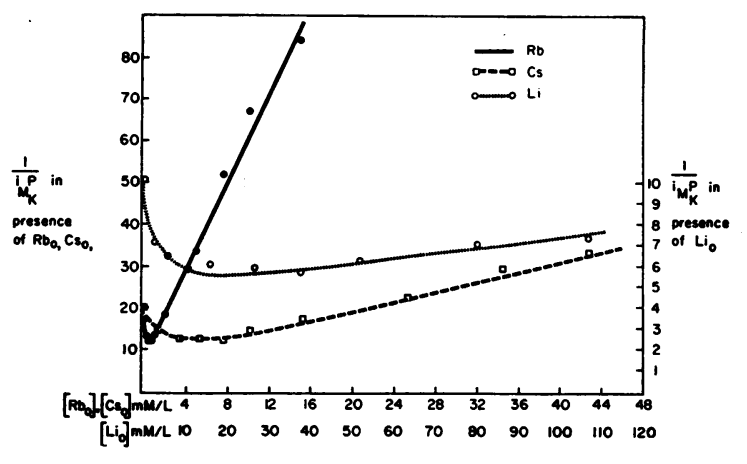

Fig. 9. THE RECIPROCAL OF THE ACTIVE POTASSIUM INFLUX, $1 /{ }^{i} \mathbf{M}_{K}{ }^{P}$ VS. THE EXTRACELLULAR CONCENTRATION OF INHIBITOR, [ $\left.I_{0}\right]$, WHERE THE INHIBITOR IS RUBIDIUM, CESIUM, OR LITHIUM. The data are the same as those plotted in Figure 8. The curve in the presence of rubidium is :

$$
\frac{1}{{ }^{i} \mathrm{M}_{\mathrm{K}}^{\mathrm{P}}}=4.0+5.55\left[\mathrm{Rb}_{\mathrm{o}}\right]+\frac{1}{0.075+0.23\left[\mathrm{Rb}_{\mathrm{o}}\right]} \text {. }
$$

$\rho=0.987$; the curve in the presence of cesium is :

$$
\frac{1}{\mathrm{i}_{\mathrm{K}} \mathrm{P}^{\mathrm{P}}}=5.0+0.63\left[\mathrm{Cs}_{\mathrm{o}}\right]+\frac{1}{0.068+0.031\left[\mathrm{Cs}_{\mathrm{o}}\right]} \text {. }
$$

$\rho=0.989$; the curve in the presence of lithium is:

$$
\begin{aligned}
& \frac{1}{i \mathrm{M}_{\mathrm{K}}^{\mathrm{P}}}=4.2+0.030\left[\mathrm{Li}_{\mathrm{o}}\right]+\frac{1}{0.17+0.056\left[\mathrm{Li}_{\mathrm{o}}\right]} . \\
& \rho=0.977 \text {. }
\end{aligned}
$$

of potassium. Studies were therefore performed to determine the "rate constant" for potassium outflux, ${ }^{\circ} \mathrm{k}_{\mathrm{K}}$, in the presence and absence of 1.5 $\mathrm{mM}$ rubidium. There was no difference in the amount of hemolysis in the presence or absence of rubidium. The results of three experiments are recorded in Table IV; the presence of rubidium does not cause an increase in ${ }^{\circ} k_{k}$. In addition, the actual supernatant potassium concentration was measured in an experiment in which the cells were incubated in the presence and absence of $20 \mathrm{mM}$ lithium for 3 hours under conditions identical to those used in measuring the active

TABLE IV

The "rate constant" for potassium outflux measured in the presence and absence of extracellular rubidium*

\begin{tabular}{ccc}
\hline \hline Sample & No rubidium & $\begin{array}{c}\text { Rubidium } \\
1.5 \mathrm{mM}\end{array}$ \\
\hline 1 & 0.020 & hour $^{-1}$ \\
2 & 0.017 & 0.019 \\
3 & 0.018 & 0.015 \\
& & 0.017 \\
\hline
\end{tabular}

* Solution contained (mmoles per L) $\mathrm{Na}^{+}, 143 ; \mathrm{Cl}^{-}, 142$; $\mathrm{PO}_{4}, 1.2 ;$ glycylglycine, $28 ; \mathrm{Mg}^{++}, 5$ or $6 ; \mathrm{K}^{+}, 0.16 ; \mathrm{Rb}^{+}$, 0 or 1.5 ; glucose, 9 . When rubidium was absent, it was replaced by magnesium. potassium influx; extracellular potassium concentration was the same after incubation both in the flasks in which lithium was present and those in which lithium was not present.

\section{Discussion}

The question of how well the model fits the results requires some consideration. The curves predicted by the model fit the data well; it is, of course, possible that equations of different forms would also fit the data. Two considerations should, however, be pointed out: 1) the curves describe the data well whether the results are plotted directly or as reciprocals, which is a fairly stringent requirement for a fitted curve, and 2) curves derived from the same model describe adequately the different varieties of experiment reported here. This is not to say that another model cannot be found that would also describe the results; however, we have not been able to find one, and, at the least, one can state that these data are compatible with the model proposed. With regard to the model itself, there is of necessity a considerable amount of ambiguity. The nature of $X$ in the model is unspecified; it might represent the entire transport process or only a small component of the process. The only requirement of the model is that potassium is required simultaneously at two "sites" and that both "sites" are saturable. It is possible that more than two potassium sites are involved, but it does not appear necessary to invoke more than two to obtain curves that fit the data. From our data it is not possible to determine whether the two sites have identical characteristics or whether they are different; such information might be obtainable from investigation of the effects of inhibitors.

The behavior of this system does not appear to be unique. Similar kinetic behavior has been reported by Jacquez (13) in the amino acid transport system of the Ehrlich ascites tumor cell. The system actively transports L-tryptophan, and the uptake of tryptophan when it is present at low concentrations is inhibited by alanine and several other amino acids at all concentrations of the competing amino acid. However, if methionine is used to compete with tryptophan, and the tryptophan is present at low concentrations, the initial flux of tryptophan is at first stimulated as the methionine concentration in- 
creases and then inhibited as the methionine concentration continues to rise. Jacquez (14) has discussed this behavior in terms of two models, either of which will explain it. Both involve a carrier system. In the first, the carrier has a site for one amino acid, but an exchange reaction may occur, i.e.,

$$
\begin{aligned}
& \mathrm{S}+\mathrm{C} \rightleftharpoons \mathrm{CS} \\
& \mathrm{I}+\mathrm{C} \rightleftharpoons \mathrm{CI} \\
& \mathrm{CI}+\mathrm{S} \rightleftharpoons \mathrm{CS}+\mathrm{I},
\end{aligned}
$$

where $S$ is the amino acid in question, $I$ the inhibiting amino acid, and $\mathrm{C}$ the carrier. From this it can be seen that, depending on the relative affinities of the two substances for $\mathrm{C}$, the concentration of CS may be higher in the presence of $\mathrm{I}$ than in its absence. If the influx, then, is proportional to the concentration of $\mathrm{CS}$, it would be expected that low concentrations of I would initially stimulate the influx of S. Jacquez points out, however, that such a system would not explain the dependence of the flux on the square of the concentration of S. Jacquez' second model involves a carrier with two sites for amino acids and is similar to the model presented here.

The involvement of more than one ion in a transport system has also been reported. Keynes and Swan (15), Mullins and Frumento (16), and Keynes (17) have shown that in frog muscle sodium outflux is proportional to the third power of the intracellular sodium concentration at low intracellular sodium concentrations, and this has been interpreted as indicating that three sodium ions are simultaneously transported outward in this system by a carrier with three sites that must be filled for transport to occur. In lactose-treated human red blood cells, McConaghey and Maizels (7) have reported that a plot of the rate constant for sodium outflux against intracellular sodium concentration yields a curve with a maximum at an intracellular sodium concentration of 10 mmoles per L. These findings would be consistent with an interpretation that more than one sodium ion is required for transport to occur.

It has been shown that a portion of the active sodium outflux requires the presence of extracellular potassium (18) and that the magnitude of this portion of the sodium outflux increases with increasing concentration of extracellular potassium until a limiting value is reached (2). Factors that affect the active potassium influx, such as cardiotonic steroids, appear to have similar effects on the potassium-dependent component of sodium outflux so that the concept of a coupled transport of sodium and potassium has been proposed (19). The results presented here are consistent with such a hypothesis, since the form of the relation of both the active potassium influx and the potassium-activated sodium outflux to the extracellular potassium concentration is the same. In the human red blood cell, Sen and Post (20) have described a "transport cycle" in which two potassium ions are transported inward and three sodium ions outward, and one ATP is split. The ionic ratios have been postulated on the basis of "coupling ratios," i.e., the number of millimoles of sodium actively transported outward divided by the number of millimoles of potassium actively transported inward. Post and Jolly (21) report for this ratio a value of 1.5 from which they conclude that three sodium ions are transported outward and two potassium ions are transported inward simultaneously. Whittam and Ager (22) have simultaneously measured sodium and potassium fluxes and ATP consumption, and they conclude that very nearly two potassium ions are transported per ATP split, and very nearly three sodium ions are transported per ATP split. Our evidence is not inconsistent with the Post hypothesis; in fact, the type of kinetics described here would necessarily follow from it. However, the fact that two potassium ions are required for the active potassium influx to occur does not necessarily mean that both are simultaneously transported. In fact, the model in the theoretical section states that only one of the two ions is transported inward whereas the other serves as a sort of activator of the system; the predictions would be the same, however, if both ions were transported inward.

It is of interest that the kinetic behavior of this system is reminiscent of the behavior of the allosteric proteins (23). Such proteins are thought to contain more than one site: one, the active site, will bind one species, e.g., a substrate; and a second nonoverlapping site will combine with some other species, thereby inducing a conformational change in the protein and so alter- 
ing the affinity of the first site for the substrate. In terms of the model presented above, it might be postulated that a potassium ion combines with a site on a membrane protein thereby inducing a conformational change in the protein; a second potassium ion would combine with the second site inducing a further conformational change that results in the deposition of potassium inside the cell. Squires (24) has investigated the activity of an $\mathrm{Na}^{+}-$and $\mathrm{K}^{+}$-activated ATPase from rat brain as a function of sodium, potassium, magnesium, and ATP concentration and has interpreted his results in terms of allosteric effects. Hokin and Yoda (25) have also discussed a complicated interaction between potassium, diisopropylfluorophosphate, ATP, strophanthidin, and an $\mathrm{Na}^{+}$- and $\mathrm{K}^{+}$-activated ATPase from beef kidney in terms of allosteric effects. It is of interest that such a hypothesis has much in common with Goldacre's proposal (26) that transport processes are mediated by foldings and unfoldings of specialized proteins; it is also of interest that Ohnishi (27) has described the presence of actin- and myosin-like proteins in the red cell membrane.

\section{References}

1. Shaw, T. I. Potassium movements in washed erythrocytes. J. Physiol. (Lond.) 1955, 129, 464.

2. Glynn, I. M. Sodium and potassium movements in human red cells. J. Physiol. (Lond.) 1956, 134, 278.

3. Hoffman, J. F. Properties of the active cation transport system in rat red blood cells. Fed. Proc. 1962, $21,145$.

4. Love, W. D., and G. E. Burch. A comparison of potassium $^{42}$, rubidium ${ }^{86}$, and cesium ${ }^{134}$ as tracers of potassium in the study of cation metabolism of human erythrocytes in vitro. J. Lab. clin. Med. 1953, 41, 351.

5. Kahn, J. B., Jr. The entry of rubidium into human erythrocytes. J. Pharmacol. exp. Ther. 1962, 136, 197.

6. Solomon, A. K. The permeability of the human erythrocyte to sodium and potassium. J. gen. Physiol. 1952, 36, 57.

7. McConaghey, P. D., and M. Maizels. Cation exchanges of lactose-treated human red cells. J. Physiol. (Lond.) 1962, 162, 485.

8. Hoffman, J. F. In preparation.

9. Ussing, H. H. The distinction by means of tracers between active transport and diffusion. The transfer of iodide across the isolated frog skin. Acta physiol. scand. 1949, 19, 43.

10. Tosteson, D. C., and J. F. Hoffman. Regulation of cell volume by active cation transport in high and low potassium sheep red cells. J. gen. Physiol. 1960, 44, 169.

11. Schatzman, H.-J. Herzglykoside als Hemmstoffe für den aktiven Kalium- und Natriumtransport durch die Erythrocytenmembran. Helv. physiol. pharmacol. Acta 1953, 11, 346.

12. Glynn, I. M. The action of cardiac glycosides on sodium and potassium movements in human red cells. J. Physiol. (Lond.) 1957, 136, 148.

13. Jacquez, J. A. Carrier-amino acid stoichiometry in amino acid transport in Ehrlich ascites cells. Biochim. biophys. Acta (Amst.) 1963, 71, 15.

14. Jacquez, J. A. The kinetics of carrier-mediated transport: stationary-state approximations. Biochim. biophys. Acta (Amst.) 1964, 79, 318.

15. Keynes, R. D., and R. C. Swan. The effect of external sodium concentration on the sodium fluxes in frog skeletal muscle. J. Physiol. (Lond.) 1959, 147, 591.

16. Mullins, L. J., and A. S. Frumento. The concentration dependence of sodium efflux from muscle. J. gen. Physiol. 1963, 46, 629.

17. Keynes, R. D. Some further observations on the sodium efflux in frog muscle. J. Physiol. (Lond.) 1965, 178, 305.

18. Flynn, F., and M. Maizels. Cation control in human erythrocytes. J. Physiol. (Lond.) 1949, 110, 301.

19. Harris, E. J. Linkage of sodium and potassium active transport in human erythrocytes in Society for Experimental Biology Symposium, VIII, Active Transport and Secretion, R. Brown and J. F. Danielli, Eds. New York, Academic Press, 1954, p. 228.

20. Sen, A. K., and R. L. Post. Stoichiometry and localization of adenosine triphosphate-dependent sodium and potassium transport in the erythrocyte. J. biol. Chem. 1964, 239, 345.

21. Post, R. L., and P. C. Jolly. The linkage of sodium, potassium, and ammonium active transport across the human erythrocyte membrane. Biochem. biophys. Acta (Amst.) 1957, 25, 118.

22. Whittam, R., and M. E. Ager. The connexion between active cation transport and metabolism in erythrocytes. Biochem. J. 1965, 97, 214.

23. Monod, J., J.-P. Changeux, and F. Jacob. Allosteric proteins and cellular control systems. J. molec. Biol. 1963, 6, 306.

24. Squires, R. F. On the interactions of $\mathrm{Na}^{+}, \mathrm{K}^{+}, \mathrm{Mg}^{++}$, and ATP with the $\mathrm{Na}^{+}$plus $\mathrm{K}^{+}$activated ATPase from rat brain. Biochem. biophys. Res. Commun. 1965, 19, 27.

25. Hokin, L. E., and A. Yoda. Effects of adenosine triphosphate, potassium, and strophanthidin on the inhibition of a ouabain-sensitive adenosine triphosphatase by diisopropylfluorophosphate. Biochim. biophys. Acta (Amst.) 1965, 97, 594.

26. Goldacre, R. J. The folding and unfolding of protein molecules as a basis of osmotic work. Int. Rev. Cytol. 1952; 1, 135.

27. Ohnishi, T. Extraction of actin- and myosin-like proteins from erythrocyte membrane. J. Biochem. (Tokyo) 1962. 52, 307. 